\title{
Results of Analysis of Cost of Growth and Feeding of Cattle
}

\author{
Hazieva A.M. \\ Department of Accounting, Statistics and Information \\ Systems in Economics \\ Bashkir State Agrarian University \\ Ufa, Russia \\ Energy_girl_88@mail.ru
}

\author{
Rafikova N.T. \\ Department of Accounting, Statistics and Information \\ Systems in Economics \\ Bashkir State Agrarian University \\ Ufa, Russia \\ rafikova163@ rambler.ru
}

\author{
Ableeva A.M. \\ Department of Accounting, Statistics and Information Systems in Economics \\ Bashkir State Agrarian University \\ Ufa, Russia \\ ableevaalisa@gmail.com
}

\begin{abstract}
In this paper, we consider the methodological aspects and the results of the analysis of the cost of production of growing and fattening cattle, taking into account the direction of development of livestock using a set of statistical methods for a long period of time. The article analyzes the cost structure; revealed the absolute and relative change in cost due to individual cost items; The analysis of factors influencing the change in the wage line for cattle of meat and dairy directions is carried out.
\end{abstract}

Keywords-analysis; cost price; cattle; milk direction; meat direction.

\section{INTRODUCTION}

In modern conditions, the need to increase the effectiveness and efficiency of control over production costs, analyze the cost of production and search for reserves to reduce it is becoming more and more relevant, as this ensures the efficient use of organization resources and the competitiveness of manufactured products.

In the context of the structural changes that began in the industry - the development of specialized meat cattle breeding, there was a need to deepen specialization and increase production concentration, to analyze the cost of growth and fattening of cattle from dairy and meat cows.

\section{LITERATURE REVIEW}

The main reason for the problems in the beef cattle breeding industry is the low profitability of beef production compared to other types of meat, the lack of an influx of investments, a decrease in meat production due to a violation of animal technologies and conditions, and price increases $[4,5]$.

For a systematic analysis of cattle breeding, it is necessary to study a large set of factors characterizing the conditions and nature of production. The internal conditions of the industry cover the technology and organization of production, feed production, reproduction and quality of the herd of animals, consumption and quality of feed, specialization and size of production, organization of labor, etc. External to enterprises the demand for livestock products in the domestic and foreign markets, the level and disparity of prices, customer monopolism, state support and regulation of the industry, climatic conditions, etc. [17].

A review of published domestic works on accounting and analysis shows that in modern conditions the focus is on the theoretical justification of the terms "zatraty na proizvodstvo", "production costs", their identity and differences [2,14,15]. Most of the works are devoted to the peculiarities of cost accounting in market conditions, the essence, the classification of costs and the cost of production (work, services) in management accounting $[7,8,9,12]$. As for cost analysis, it is proposed to use the "Direct-Costing " system in agricultural production management with the allocation of variables and fixed costs, their impact on financial results $[1,3,7,8,9,13]$.

In our opinion, the introduction of management accounting, budgeting of costs primarily depends on how much the basic principles of accounting, cost analysis and production costs accepted in domestic practice are observed.

The aim of the research is to improve the methodology of cost analysis and cost of livestock production in modern conditions.

\section{Research Methodology}

The study was conducted on the materials of agricultural organizations of the Republic of Bashkortostan with the integrated use of structure and dynamics analysis methods, average and relative values, index analysis, tables.

At the first stage of the study, an analysis was made of the cost of growth of cattle in the dairy sector by cost items in agricultural organizations of the Republic of Bashkortostan. 
Subsequently, the same analysis was carried out on the growth of cattle in the meat sector.

At the final stage, an analysis of factors affecting costs was carried out under the item "Payment" of labor with deductions for social needs.

\section{RESULTS}

Due to the variety of cost factors and their various combinations, a detailed analysis of the conditions for the formation of cost and search for its reduction is required. An analysis of the cost livestock products was carried out over a long period of time, including the stages of the state programs implementation for the development of agriculture. For a comparative assessment, the base period was chosen in 2009, since then the list of articles reflecting material costs has been clarified in the annual reports of agricultural organizations.

From the presented table 1 it can be seen that the cost of 1 centner of the growth in beef cattle breeding increased in 2017 compared to 2009 by $40.6 \%$. From a comparison of the dynamics of costs in the context of certain types of costs, it follows that the costs of articles: electricity, oil products, other costs, and feed costs are increasing rapidly. At the same time, the costs under the main "Feed" item increased at a relatively slower pace. It is explained primarily by the fact that cheap coarse and green fodder obtained from pastures and hayfields occupy a large share in the diets of beef cattle. Taking into account structural changes and the dynamics of certain types of costs, the increase in cost for the analyzed years was due to $83.3 \%$ absolute and relative increase in feed costs and labor costs.

TABLE I. ANALYSIS OF THE GROWTH COST IN THE CULTIVATION AND FATTENING OF MEAT DIRECTION IN AGRICULTURAL ORGANIZATIONS OF THE REPUBLIC OF BASHKORTOSTAN

\begin{tabular}{|c|c|c|c|c|c|c|c|}
\hline \multirow[t]{2}{*}{ Cost types } & \multicolumn{2}{|c|}{$\begin{array}{c}\text { Cost } \\
\text { structure, } \\
\%\end{array}$} & \multicolumn{2}{|c|}{$\begin{array}{c}\text { Cost of } 1 \\
\text { centner of } \\
\text { growth, rub. }\end{array}$} & \multirow{2}{*}{$\begin{array}{c}\text { Index } \\
\text { the } \\
\text { costs, } \\
\%\end{array}$} & \multicolumn{2}{|c|}{$\begin{array}{l}\text { Change in cost } \\
\text { due to certain } \\
\text { types of costs }\end{array}$} \\
\hline & $\begin{array}{c}200 \\
9\end{array}$ & $\begin{array}{c}201 \\
7\end{array}$ & 2009 & 2017 & & $\begin{array}{c}\text { absolut } \\
\text { e, } \\
\text { rub. }\end{array}$ & $\begin{array}{c}\text { relativ } \\
\mathrm{e}, \\
\%\end{array}$ \\
\hline $\begin{array}{l}\text { Wages } \\
\text { with social } \\
\text { contributio } \\
\text { ns }\end{array}$ & 18,4 & 18,4 & $\begin{array}{c}1366 \\
8\end{array}$ & 1921,7 & 140,6 & $+554,9$ & $+7,5$ \\
\hline Feed & 49,5 & 53,9 & $\begin{array}{c}3676, \\
9\end{array}$ & 5629,3 & 153,1 & $\begin{array}{c}+1952, \\
4\end{array}$ & $+26,3$ \\
\hline $\begin{array}{l}\text { Fixed } \\
\text { assets }\end{array}$ & 15,0 & 9,4 & $\begin{array}{c}1114, \\
2\end{array}$ & 981,7 & 88,1 & $-132,5$ & $-1,8$ \\
\hline $\begin{array}{l}\text { Electric } \\
\text { power }\end{array}$ & 2,0 & 2,7 & 148,6 & 282,0 & 189,8 & $+133,4$ & $+1,8$ \\
\hline $\begin{array}{l}\text { Oil - } \\
\text { products }\end{array}$ & 4,4 & 5,1 & 326,8 & 532,6 & 163,0 & $+205,8$ & $+2,8$ \\
\hline $\begin{array}{l}\text { Other } \\
\text { expendi- } \\
\text { tures }\end{array}$ & 10,7 & 10,5 & 794,8 & 1096,6 & 138,0 & $+301,8$ & $+4,1$ \\
\hline Total & $\begin{array}{c}100, \\
0\end{array}$ & $\begin{array}{c}100, \\
0\end{array}$ & $\begin{array}{c}7428 \\
1\end{array}$ & $\begin{array}{c}10444, \\
0\end{array}$ & 140,6 & $\begin{array}{c}+3015 \\
9\end{array}$ & $+40,6$ \\
\hline
\end{tabular}

As for the cost price of livestock growth from milk direction cows, in 2017 its level is higher than from the livestock of the meat direction. At the same time, the growth rates for all cost items are significantly higher compared to other costs. The cost of growth in 2017 compared to 2009 increased by $106.0 \%$. This was due to a $73.9 \%$ absolute and relative increase in the cost of feed, wages (table 2).

Due to the article "Wages with social contributions", the cost of 1 centner of growth in 2017 compared to 2009 increased by $7.5 \%$ in beef cattle breeding, and in dairy - by $23.0 \%$.

TABLE II. ANALYSIS OF THE COST OF GROWTH IN THE CULTIVATION AND FATTENING OF MILK DIRECTION IN AGRICULTURAL ORGANIZATIONS OF THE REPUBLIC OF BASHKORTOSTAN

\begin{tabular}{|c|c|c|c|c|c|c|c|}
\hline \multirow{2}{*}{ Cost types } & \multicolumn{2}{|c|}{$\begin{array}{c}\text { Cost } \\
\text { structure, } \\
\% \\
\end{array}$} & \multicolumn{2}{|c|}{$\begin{array}{c}\text { Cost of } 1 \\
\text { centner of } \\
\text { growth, rub. }\end{array}$} & \multirow{2}{*}{$\begin{array}{c}\text { Index } \\
\text { the } \\
\text { costs, } \\
\%\end{array}$} & \multicolumn{2}{|c|}{$\begin{array}{l}\text { Change in cost } \\
\text { due to certain } \\
\text { types of costs }\end{array}$} \\
\hline & $\begin{array}{c}200 \\
9\end{array}$ & $\begin{array}{c}201 \\
7\end{array}$ & 2009. & 2017 & & $\begin{array}{c}\text { absolut } \\
\text { e, } \\
\text { rub. }\end{array}$ & $\begin{array}{l}\text { relativ } \\
\text { e, } \\
\%\end{array}$ \\
\hline $\begin{array}{l}\text { Wages } \\
\text { with social } \\
\text { contributio } \\
\text { ns }\end{array}$ & 18,6 & 20,2 & $\begin{array}{c}1180, \\
9\end{array}$ & 2642,6 & 223,8 & $\begin{array}{c}+1461, \\
7\end{array}$ & $+23,0$ \\
\hline Feed & 51,8 & 52,0 & $\begin{array}{c}3288, \\
8\end{array}$ & 6802,6 & 206,8 & $\begin{array}{c}+3513, \\
8\end{array}$ & $+55,3$ \\
\hline $\begin{array}{l}\text { Fixed } \\
\text { assets }\end{array}$ & 6,1 & 9,0 & 387,3 & 1177,4 & 304,0 & $+790,1$ & $+12,4$ \\
\hline $\begin{array}{l}\text { Electric } \\
\text { power }\end{array}$ & 2,9 & 2,8 & 184,1 & 366,3 & 199,0 & $+182,2$ & $+2,9$ \\
\hline $\begin{array}{l}\text { Oil - } \\
\text { products }\end{array}$ & 3,6 & 4,4 & 228,6 & 575,6 & 251,8 & $+347,0$ & $+5,5$ \\
\hline $\begin{array}{l}\text { Other } \\
\text { expendi- } \\
\text { tures }\end{array}$ & 17,0 & 11,6 & $\begin{array}{c}1079, \\
3\end{array}$ & 1517,5 & 140,6 & $+438,2$ & $+6,9$ \\
\hline Total & $\begin{array}{c}100, \\
0\end{array}$ & $\begin{array}{c}100, \\
0\end{array}$ & $\begin{array}{c}6349, \\
0\end{array}$ & $\begin{array}{c}13082, \\
0\end{array}$ & 206,0 & $\begin{array}{c}+6733, \\
0\end{array}$ & $\begin{array}{c}+106, \\
0\end{array}$ \\
\hline
\end{tabular}

The change in cost due to the article "Wages with social contributions" depends on the ratio of productivity growth rates and the level of remuneration. During the analyzed period, productivity increased and labor costs per 1 head of cattle decreased. This contributed to an increase in labor productivity in beef cattle breeding by $85.2 \%$, and in dairy cattle breeding by $62.3 \%$. As a result, the share of costs for paying direct labor costs increased in dairy cattle breeding from 18.6 to $20.2 \%$, but did not change in beef cattle breeding. At the same time, the level of payment for 1 person-hour in the production of weight gain in cattle breeding in the dairy direction increased 2.5 times, and in beef cattle breeding by 93.3\%.

Subsequently, using the index analysis, the influence of certain factors on the formation and dynamics of the article "Wages with social contributions" was established (table 3). 
TABLE III. ANALYSIS OF FACTORS AFFECTING COSTS UNDER THE ARTICLE "REMUNERATION OF LABOR WITH DEDUCTIONS FOR SOCIAL NEEDS" IN AGRICULTURAL ORGANIZATIONS REPUBLIC OF BASHKORTOSTAN

\begin{tabular}{|l|c|c|c|c|c|c|}
\hline \multirow{2}{*}{ Indicators } & \multicolumn{2}{|c|}{ cattle of milk direction } & \multicolumn{2}{c|}{ cattle of meat direction } \\
\cline { 2 - 7 } & 2009 & 2017 & $\begin{array}{c}2017 \\
\text { K } \\
2009, \\
\%\end{array}$ & 2009 & 2017 & $\begin{array}{c}2017 \\
\text { K } \\
2009, \\
\%\end{array}$ \\
\hline $\begin{array}{l}\text { Costs under the } \\
\text { article } \\
\text { "Remuneration of } \\
\text { labor" per 1 goal, } \\
\text { rub. }\end{array}$ & 1795 & 3819 & 212,8 & 2597 & 3443 & 132,6 \\
\hline $\begin{array}{l}\text { For 1 centner } \\
\text { growth, rub. }\end{array}$ & 1180,9 & 2402,0 & 203,4 & 1366,8 & 1774,9 & 129,9 \\
\hline $\begin{array}{l}\text { Payment 1 person- } \\
\text { hour, rub. }\end{array}$ & 38,7 & 96,9 & 250,4 & 40,6 & 78,5 & 193,3 \\
\hline $\begin{array}{l}\text { Direct labor costs } \\
\text { for 1 goal, person- } \\
\text { hour }\end{array}$ & 46,3 & 31,1 & 67,1 & 64,0 & 37,0 & 57,8 \\
\hline $\begin{array}{l}\text { At 1 centner } \\
\text { growth, person- } \\
\text { hour }\end{array}$ & 30,5 & 18,8 & 61,6 & 33,7 & 18,2 & 54,0 \\
\hline $\begin{array}{l}\text { The gain on 1 } \\
\text { goal., centner }\end{array}$ & 1,52 & 1,65 & 108,6 & 1,90 & 2,04 & 107,4 \\
\hline
\end{tabular}

In beef cattle breeding, labor is less qualified due to the low level of mechanization, old technologies for keeping animals, and a small share of production in livestock complexes. This adversely affects the cost of production, does not contribute to increased productivity and labor productivity.

A higher level of labor productivity in beef cattle breeding is explained by the relatively high productivity of beef cattle. Based on the analytical grouping of districts of the Republic of Bashkortostan in terms of the average daily weight gain of animals for growing and fattening, it was found that the production of raising and fattening cattle from dairy cows exceeds the amount of produced products from specialized meat breeds by almost 9.7 times. In this regard, the need has arisen for the development of specialized beef cattle breeding in the region, increasing the level of specialization and concentration of production, which allows for expanded reproduction in the industry, as evidenced by the experience of enterprises in the Bryansk, Voronezh and Belgorod regions. Along with the development of specialized meat cattle breeding, productivity should be increased in the cultivation and fattening of young animals obtained from dairy herd cows; to expand the cultivation and fattening of cross-breeding cattle in the Northern forest-steppe, and beef cattle - in the Northern, North-Eastern and Mountain-forest zones with sufficient pasture areas, contributing to a significant reduction in feed costs $[10,11,12]$. The costs under the item "Feed" play a major role in the formation of the cost of livestock production and are determined by the consumption of feed per 1 centner the gain and the cost of 1 centner unit. feed. The analysis of the factors that form the costs of the article "Feed" depending on the direction of development of livestock breeding is significantly complicated due to the lack of data in the annual reports of enterprises on the quantity, structure and quality of spent feed. Such an analysis can be carried out only at the enterprise level in a selective way.
In-depth studies and approbation of the results were reviewed and approved at a meeting of the section of the Scientific and Technical Council on Economics and Organization of Agricultural Production of the Ministry of Agriculture of the Republic of Bashkortostan

\section{DISCUSSION}

In [6] the costs are studied in energy units, not in monetary terms. This is due to the fact that the production of cattle gain is less energy-intensive compared to the greenhouse production of fruits and vegetables, including the cost of fertilizers, diesel fuel, irrigation water and labor. In the work of Narges Banaeian, Mahmoud Omid, Hojat Ahmadi, the Cobb-Douglas function was used to determine the distribution of energy resources. In our opinion, it is necessary to ensure economic comparability when analyzing the dynamics of the cost of production and its factors, taking into account the situation in the economy, the features of production and the formation of the cost of livestock products in the region, as well as ongoing state programs for the development of agriculture $[16,17,18]$.

\section{CONCLUSION}

The proposed analysis technique allowed: firstly, to take into account the specifics of the technology for raising livestock in various directions; secondly, to take into account the fact that the main production of cultivation products occurs, as a rule, at the expense of culled cows and overrepairs of young dairy and combined breeds. The analysis in [14] showed that "along with the development of specialized meat cattle breeding, productivity should be increased in the cultivation and fattening of young animals obtained from dairy herd cows."

In agricultural organizations of the Republic of Bashkortostan, a positive trend in the management of production costs has been identified. Further development of cattle breeding and the production of high-quality beef are limited by price factors affecting cost items, as well as by relatively low wages in agriculture. All this requires continuous monitoring and an independent audit of costs in agriculture, tariffs in the energy sector and a comprehensive analysis of production costs and production costs.

\section{References}

[1] Avdonina I.A. the use of "Direct-costing" system in the management of agricultural production. Economics and entrepreneurship. 2017, 8-3(853), pp. 757-764.

[2] Gataulin, A.M. production Costs of agricultural products. M.: Economics. $1983,184$.

[3] Kovanov D.I., Yakovleva N.A. Application of statistical methods in the analysis of factors determining the level of milk cost. Innovative economy: prospects of development and improvement. 2016, 8(18), pp. 76-81.

[4] Lagun, A.A., Medvedeva, N.A. Enhancement of milk cattle reproduction economic efficiency. Dairy business bulletin. 2011, 1, pp. 73-80.

Lagun, A.A., Medvedeva, N. A. Some aspects of meat cattle breeding efficiency assessment of the region. Bulletin of Agro-industrial complex of Verkhnevolzh'ya. 2014, pp. 18-21.

[5] Mohammadi, A., Rafiee, S., Mohtasebi, S. S., \& Rafiee, H. Energy inputs-yield relationship and cost analysis of kiwifruit production in Iran. Renewable energy. 2010, 35(5), pp. 1071-1075. 
[6] Nikolaeva S. A. Features of cost accounting in the market conditions. Direct costing system. Finance and statistics. M. 1993, 128.

[7] Nikolaev, S.A., Principles of formation and calculation of the cost. Moscow: Analitika - Press. 1997, 142.

[8] Modern methods of calculation and analysis of the cost of production (services) and the possibility of their application in domestic practice. Achievements and innovations in science, technology and medicine: collection of articles of the international scientific-practical conference. 2016, pp. 57-61.

[9] Rafikova N.T. Cost of agricultural products-factors and methodology of analysis. M.: Finance and statistics. 1999, 301.

[10] Rafikova N.T., Khaziyeva, A. M., Statistical approach to the analysis of the production costs of growing and fattening cattle. Economy and management: scientific-practical journal. 2017, 2(136), pp. 48-56.

[11] Rafikova, N.T. Analysis of the average annual rate of change in the cost of milk, its structure and factors. Science of the XXI century: current trends of development. 2017, 1-2, pp. 302-308.

[12] Rafikova N.T., Bakirova R. R. Analysis of dynamics of cost of milk and its structure in the Republic of Bashkortostan. The Russian village and cooperation: today and tomorrow: proceedings of the International scientific-practical conference, Yaroslavl-Moscow, March 01. 2017, pp. 169-174.

[13] Rafikova N.T., Khaziyeva A. M.-sufficiency ratios in meat products and the development of cattle breeding in the Republic of Bashkortostan. Economics and management: scientific-practical journal. 2016, 4, pp. 7680.

[14] Titova O.V. product cost management using the results of break-even analysis to improve the financial policy of the enterprise. Competitiveness in the global world: Economics, science, technology. 2016, 7-2(19), pp. 138-139.

[15] Zinchenko A.P. Economic and statistical analysis of agriculture: collection of articles. M.: Publishing house of Russian state agrarian University - MTAA. 2012, 457.

[16] Alexsandr S. Kuznetsov. Russian Professor's meeting. Russian Journal of Physical Education and Sport. 2019, 14(1), pp. 17-22. DOI: 10.14526/2070-4798-2019-14-1-18-24

[17] Zinchenko, A. P., Kagirova, M. V. Cattle-breeding efficiency in Russia in the period of agricultural development state programs realizations. Bulletin of Timiryazev agricultural academy. 2015, 1, pp. 108-124. 